\title{
EFEK ANTI INFLAMASI SARI BUAH NANAS (Ananas comosus L.) DAN APEL HIJAU (Pyrus malus L.) PADA TIKUS PUTIH JANTAN (Rattus norvegicus L.)
}

\author{
Dimas Aqil Fikrinda*, Jaka Fadraersada, Laode Rijai \\ Laboratorium Penelitian dan Pengembangan FARMAKA TROPIS \\ Fakultas Farmasi Universitas Mulawarman, Samarinda, Kalimantan Timur \\ *email : dimasaqilfikrinda@gmail.com
}

\begin{abstract}
ABSTRAK
Inflamasi merupakan suatu respons protektif normal terhadap luka jaringan yang disebabkan trauma fisik, zat kimia, atau zat mikrobiologik. Nanas mengandung enzim bromelain yang merupakan enzim proteolitik dan apel mengandung senyawa-senyawa flavonoid seperti kuersetin, keduanya memiliki efek antiinflamasi. Tujuan penelitian ini adalah untuk mengetahui konsentrasi sari buah nanas (Ananas comosus L.) dan apel hijau (Pyrus malus L.) sebagai anti inflamasi dengan metode pletismometer setiap 60 menit selama 6 jam yang dibandingkan dengan natrium diklofenak. Hewan uji diberikan secara oral 1 jam sebelum diinduksi dengan 0,1 mL karaginan $2 \%$. Hewan uji dibagi ke dalam IV kelompok, masingmasing kelompok terdiri dari 3 ekor hewan uji. Kelompok I kontrol (-) Na CMC 0,5\%, kelompok II kontrol (+) natrium diklofenak $50 \mathrm{mg}$, kelompok III konsentrasi terbaik nanas tunggal 60\%, dan kelompok IV konsentrasi terbaik apel tunggal 56\%. Hasil volume telapak kaki yang didapatkan, dilaporkan secara deskriptif antara sari buah nanas tunggal dibandingkan Natrium diklofenak pada jam ke 1 dan ke 6 yaitu 4,59 mL dengan 4,06 mL; 4,05 mL dengan 4,01 mL. Kemudian sari buah apel tunggal dibandingkan Natrium diklofenak pada jam ke 1 dan ke 6 yaitu 4,67 mL dengan 4,06 mL ; 4,01 mL dengan 4.01 $\mathrm{mL}$. Dapat disimpulkan bahwa sari buah nanas dan apel hijau memiliki potensi yang lebih kecil sebagai antiinflamasi dibandingkan dengan natrium diklofenak $50 \mathrm{mg}$.
\end{abstract}

Kata Kunci : Ananas comosus L., Antiinflamasi, Na.diklofenak, Pyrus malus L., Tikus Putih

\section{ABSTRACT}

Inflammation is a normal protective response by a tissue damages that caused by physical trauma, chemical, or microbiological substances. Pineapple contain bromelain enzyme which is proteolythic enzymes, and apple contains flavonoid compounds, such as quersetin, both have antiinflammation effects. The purpose in were to find out the concentrations of pineapple and green apple juice as antiinflammation by using pletismometer every 60 minutes in 6 hours, compared to positive control Sodium Diclofenac. Test animals were orally given 1 hour earlier before being induced by $0,1 \mathrm{~mL}$ caragenan $2 \%$. The test animals were divided into 4 groups, each group has 3 animal tests. Group 1 is (-) control Na CMC $0,5 \%$, group 2 is (+) control Sodium Diclofenac, group 3 is $60 \%$ concentration of single 
pineapple whitch is the best concentration of pineapple juice and group 4 is the best concentration single apple $56 \%$. The results of the foot volumes that reported descriptively between single pineapple and Sodium Diclofenac are 4,59 $\mathrm{mL}$ and 4,06 $\mathrm{mL} ; 4,05 \mathrm{~mL}$ and 4,01 mL. And results between single apple and Sodium Diclofenac are 4,67 $\mathrm{mL}$ and 4,06 ; 4,01 $\mathrm{mL}$ and 4,01 $\mathrm{mL}$. From the results, it is known that pineapple juice and apple juice the potential is still small compared with the extract of diclofenac sodium $50 \mathrm{mg}$.

Keywords : Ananas comosus L., Antiinflammatory, Sodium diclofenac, Pyrus malus L.

\section{PENDAHULUAN}

Inflamasi merupakan suatu respons protektif normal terhadap luka jaringan yang disebabkan oleh trauma fisik, zat kimia yang merusak, atau zat- zat mikrobiologik. Inflamasi juga adalah usaha tubuh untuk menginaktivasi atau merusak organisme yang menyerang, menghilangkan zat iritan, dan mengatur derajat perbaikan jaringan (Mycek, dkk., 2001). Obat sintetik yang banyak digunakan untuk mengatasi inflamasi adalah kelompok obat Anti Inflamasi Non Steroid (AINS) dan kortikosteroid. Penggunaan obat-obat tersebut menimbulkan reaksi obat yang tidak diinginkan (ROTD) dan yang sering terjadi adalah gangguan saluran pencernaan (Katzung, 2006), sehingga perlu dilakukan penelitian untuk mencari terapi alternatif yang memiliki ROTD ringan.

Bromelain adalah nama umum dari famili enzim proteolitik yang didapat dari Ananas comosus.,L atau tanaman nanas. Penggunaan bromelain yang paling sering adalah agen antiinflamasi dan anti-edema, antitrombotik, dan aktivitas fibrinolitik telah dilaporkan (Contreras dkk, 2008). Efek dari buah nanas pada dosis 20 dan $40 \mathrm{mg} / \mathrm{kg}$ membuktikan buah nanas mempunyai efek antiinflamasi (Sudjarwo, 2005).

Kuersetin adalah salah satu flavonoid yang banyak ditemukan pada sayuran dan buahbuahan, biasanya dalam bentuk glikosidanya. Dalam buah apel, kuersetin banyak ditemukan dalam konsentrasi yang tinggi. Terdapat banyak khasiat yang dimiliki oleh kuersetin, dalam skala industri digunakan sebagai suplemen dan dipromosikan sebagai anti inflamasi dan antioksidan alami (Hoffmann, 2003). Efek dari apel hijau pada dosis $10 \mathrm{mg} / \mathrm{kg}$ membuktikan bahwa apel hijau mempunyai efek antiiflamasi (Morikawa, 2003).

Kandungan bromelain pada nanas dan kandungan kuersetin pada apel hijau memiliki aktifitas anti inflamasi. Tetapi sampai saat ini belum ada penelitian mengenai efek analgesik kombinasi sari buah nanas (Ananas comosus L.) dan apel hijau (Pyrus malus L.).

\section{METODE PENELITIAN}

\section{Bahan}

Bahan yang digunakan dalam penelitian ini adalah sari buah nanas dan apel hijau, karagenan, $\mathrm{NaCl}$ fisiologis $0,9 \%$, natrium diklofenak, $\mathrm{Na}-\mathrm{CMC}$ dan air suling.

Hewan percobaan yang digunakan adalah tikus putih jantan berumur sekitar 3-4 bulan dengan berat 130-220 gram dan sehat.

\section{Peralatan}

Alat-alat yang digunakan dalam penelitian ini adalah alat untuk membuat sari buah, blender, timbangan analitik, inkubator, spoid, sonde, labu ukur, pletismometer dan alat gelas penunjang lainnya. 


\section{Prosedur}

\section{Penyiapan dan Pembuatan Sari Buah}

Penyiapan sampel bahan yang akan diuji dilakukan dengan mengambil bagian dari daging buah nanas dan apel hijau. Buah dipilih berdasarkan tingkat kematangannya. Buahbuah yang telah busuk, terlalu matang atau yang terlihat sifat tidak normal dipisahkan agar tidak mempengaruhi mutu akhir produk. Buah yang telah disortir kemudian dicuci dengan menggunakan air bersih untuk menghilangkan kotoran yang terdapat pada permukaan buah. Bagian buah yang tidak dapat dimakan dibuang. Kemudian dipotong kecil-kecil dan dihaluskan dengan menggunakan blender tanpa penambahan air. Sebelum daging buah tersebut dihaluskan, terlebih dahulu ditimbang berat awal dari buah. Kemudian jus buah nanas dan apel hijau yang diperoleh disaring dengan menggunakan penyaring untuk menghilangkan ampasnya. Sari buah yang diperoleh diukur volumenya untuk dihitung konsentrasi.

\section{Persiapan Hewan Uji}

Semua hewan uji dipelihara dalam kondisi yang sama. Sebelum digunakan, tikus diadaptasikan dengan lingkungan penelitian selama dua minggu dan sebelum pengujian tikus dipuasakan \pm 18 jam dengan tetap diberi minum.

\section{Pengujian Aktivitas Anti Inflamasi}

Dibagi tikus menjadi empat kelompok yang masing-masing berisi 3 ekor tikus. Diberi tanda pada kaki tikus untuk memberi batas pada saat pengukuran pada alat. Kemudian dilakukan perlakuan pada masing-masing kelompok.

Perlakuan yang diberikan pada masing-masing kelompok adalah

- Kontrol negatif suspensi Na CMC $0.5 \%$

- Kontrol positif suspensi obat natrium diklofenak $50 \mathrm{mg}$

- Kelompok uji 1; sari buah nanas tunggal

- Kelompok uji 2; sari buah apel hijau tunggal

Setelah itu dilakukan pengukuran volume kaki tikus putih yang dinyatakan sebagai volume awal $\left(\mathrm{V}_{0}\right)$ dengan cara mencelupkan kaki tikus ke dalam bejana hingga tanda batas. Pada setiap pengukuran tinggi cairan pada alat harus sama.

Dibersihkan kaki tikus dengan alkohol, kemudian telapak kaki tikus diinduksi karagenan $2 \%$ sebanyak $0,1 \mathrm{~mL}$ secara intraplantar. Diukur volume udem kaki tikus setiap 60 menit selama 6 jam dengan pletismometer.

\section{HASIL DAN PEMBAHASAN}

\section{Aktivitas Antiinflamasi Sari Buah}

Pengukuran volume udem pada telapak kaki tikus dilakukan setiap 60 menit selama 6 jam setelah telapak kaki tikus diinduksi karagenan agar terjadi inflamasi. Pengamatan selama 6 jam dilakukan untuk mengetahui waktu dimana volume radang maksimal terbentuk. Pada penelitian ini, volume radang rata-rata kelompok kontrol negatif yang diberikan Na-CMC meningkat mulai jam pertama sampai jam keempat, volume radang terbesar terjadi pada jam keempat. Lalu mulai mengalami penurunan pada jam kelima hingga keenam namun belum dapat mengembalikan volume radang pada kaki tikus sampai ke volume normal.

Dari hasil penelitian menunjukkan bahwa sari buah nanas dan apel hijau mampu menghambat radang. Volume radang pada telapak kaki tikus yang lebih kecil dari kelompok 
kontrol negatif menunjukkan bahwa konsentrasi sari buah tunggal mampu menekan radang yang disebabkan oleh karagenan. Tampak adanya perbedaan volume radang antara kelompok kontrol negatif dan konsentrasi sari buah. Pada kelompok kontrol negatif yang diberikan $\mathrm{Na} \mathrm{CMC}$, volume radang meningkat mulai dari jam pertama sampai jam keempat, sedangkan pada kelompok perlakuan konsentrasi nanas tunggal volume radang mengalami kenaikan mulai terjadi pada jam pertama hingga jam ketiga, lalu pada jam keempat hingga keenam mengalami penurunan. Pada konsentrasi apel tunggal, peningkatan volume radang mulai terjadi pada jam pertama hingga jam ketiga dan kemudian mulai mengalami penurunan volume bengkak pada jam keempat hingga keenam.

Tabel 1. Volume radang rata-rata telapak kaki tikus

\begin{tabular}{ccccccccc}
\hline & \multicolumn{7}{c}{ Rata-rata Volume Telapak Kaki (mL) } \\
\cline { 2 - 8 } Perlakuan Uji & $\begin{array}{c}\text { Sebelum } \\
\text { Induksi }\end{array}$ & $\begin{array}{c}\text { Jam } \\
\text { ke }\end{array}$ & $\begin{array}{c}\text { Jam } \\
\text { ke 2 }\end{array}$ & $\begin{array}{c}\text { Jam } \\
\text { ke 3 }\end{array}$ & $\begin{array}{c}\text { Jam } \\
\text { ke 4 }\end{array}$ & $\begin{array}{c}\text { Jam } \\
\text { ke 5 }\end{array}$ & $\begin{array}{c}\text { Jam } \\
\text { ke 6 }\end{array}$ \\
\hline $\begin{array}{c}\text { Kontrol } \\
\text { Negatif }\end{array}$ & 3.32 & 4.14 & 5.12 & 5.45 & 5.71 & 4.55 & 4.07 \\
$\begin{array}{c}\text { Konsentrasi } \\
\text { Positif }\end{array}$ & 3.32 & 4.06 & 4.29 & 4.5 & 4.46 & 4.02 & 4.01 \\
$\begin{array}{c}\text { Konsentrasi } \\
\text { Apel Tunggal } \\
\text { Kontrol Nanas } \\
\text { Tunggal }\end{array}$ & 3.89 & 4.67 & 5.06 & 5.48 & 5.47 & 4.68 & 4.01 \\
\hline
\end{tabular}

\section{Konsentrasi Efektif Sari Buah Nanas dan Apel Hijau}

Berdasarkan tabel 1 didapatkan konsentrasi efektif sari buah nanas tunggal yaitu $60 \%$ dan sari buah apel hijau tunggal yaitu 56\%. Konsentrasi efektif merupakan konsentrasi sari buah uji yang memiliki aktivitas antiinflamasi yang optimal dibandingkan dengan variasi atau konsentrasi sari buah uji lainnya. Hal ini dapat dilihat pada tabel 1 dimana pada sari buah nanas konsentrasi 60\% dan apel hijau konsentrasi 56\% mampu dalam menurunkan volume radang kaki tikus walaupun pada jam ke enam belum mengembalikan volume kaki tikus ke volume normal.

Hasil analisis statistik uji kenormalan data menunjukkan bahwa nilai sig $>0,05$, sehingga keputusan $\mathrm{H}_{0}$ diterima dan keputusan $\mathrm{H}_{1}$ ditolak.dengan demikian maka dapat disimpulkan bahwa data yang diperoleh terdistribusi secara normal dan homogen. Kemudian, setelah dilakukannya uji kenormalan data, dilanjutkan dengan analisis uji signifikansi pengaruh variasi konsentrasi terhadap aktivitas antiinflamasi. Hasil analisis uji signifikansi pengaruh variasi konsentrasi terhadap aktivitas antiinflamasi diperoleh nilai sig $<0,05$, sehingga keputusan $\mathrm{H}_{0}$ ditolak dan keputusan $\mathrm{H}_{1}$ diterima.

Dengan demikian dapat disimpulkan bahwa terdapat pengaruh yang signifikan antara variasi konsentrasi uji sari buah nanas dan apel hijau terhadap aktivitas antiinflamasi yang dihasilkan. Setelah itu dilakukan uji lanjutan yaitu uji duncan. Berdasarkan uji duncan dapat diketahui bahwa kontrol negatif berada dalam subset yang berbeda dengan variasi konsentrasi sari buah. Hal ini menunjukkan bahwa aktivitasi antiinflamasi kontrol negatif berbeda signifikan dengan masing-masing variasi konsentrasi sari buah. Berdasarkan uji 
tersebut dapat diketahui bahwa konsentrasi sari buah efektif yang beraktivitas sebagai antiinflamasi adalah konsentrasi sari buah nanas 60\% dan apel hijau 56\%.

Konsentrasi sari buah nanas 60\% dan apel hijau 56\% dipilih sebagai konsentrasi sari buah efektif karena konsentrasi tersebut sudah memiliki aktivitas antiinflamasi terhadap penurunan volume radang kaki tikus . Artinya adalah konsentrasi sari buah nanas $60 \%$ dan apel hijau 56\% sudah dapat memberikan efek yang efektif dan mampu dalam menurunkan volume radang telapak kaki tikus.

\section{Potensi Antiinflamasi Sari Buah Nanas dan Apel Hijau}

Penentuan potensi antiinflamasi sari buah nanas dan apel hijau dilakukan dengan menggunakan kontrol positif berupa natrium diklofenak. Hasil dari pengujian natrium diklofenak, kemudian dibandingkan dengan sari buah nanas dan apel hijau dengan konsentrasi efektif yaitu $60 \%$ dan 56\%. Berdasarkan gambar 2 dapat dilihat bahwa konsentrasi sari buah nanas $60 \%$ dan apel hijau 56\% memberikan efek penurunan volume radang pada jam ke 4 dan sama halnya dengan kontrol positif yang memberikan efek penurunan radang pada jam ke 4 .

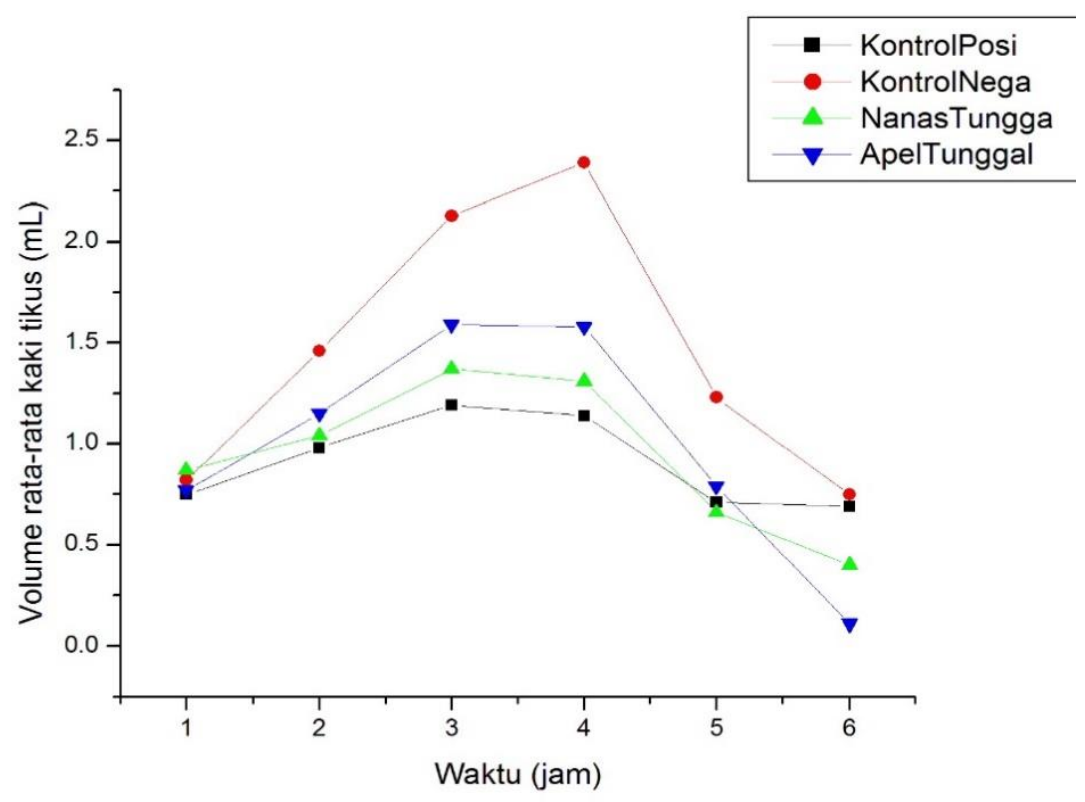

Gambar 1. Grafik perbandingan penurunan volume kaki tikus putih

Waktu ketersediaan hayati pada pemberian sari buah nanas dan apel hijau dengan kontrol positif di dalam darah setelah absorpsi pada gastrointestinal sama ditandai dengan waktu penurunan volume radang yang sama pada kedua perlakuan. Kedua pemberian tersebut dapat berikatan pada reseptor pada jam ke 4 dan mampu menurunkan radang secara bersamaan. Maka untuk memastikan perbandingan potensi lebih lanjut antara konsentrasi sari buah nanas $60 \%$ dan apel hijau 56\% dengan kontrol positif dapat dilakukan uji t.

Berdasarkan uji t diperoleh nilai sig dari konsentrasi uji efektif sari buah dan kontrol positif $<0,05$, sehingga keputusan $\mathrm{H}_{0}$ ditolak dan keputusan $\mathrm{H}_{1}$ diterima, hal ini 
menunjukkan bahwa konsentrasi uji efektif sari buah nanas dan apel hijau dan kontrol positif natrium diklofenak $50 \mathrm{mg}$ berbeda secara signifikan dalam memberikan efek antiinflamasi. Dari uji tersebut telah membuktikan bahwa konsentrasi sari buah nanas $60 \%$ dan apel hijau $56 \%$ memiliki potensi yang lebih kecil dibandingkan dengan natrium diklofenak dalam menurunkan volume radang pada telapak kaki tikus ditinjau dari waktu penurunan volume radang pada jam ke 4 .

Hal ini diduga karena kandungan dari enzim bromelain pada nanas dan senyawa flavanoid yaitu kuarsetin pada apel hijau yang mekanisme kerjanya sama dengan natrium diklofenak yaitu menghambat enzim siklooksigenase sehingga tidak terbentuk mediator nyeri yang menyebabkan inflamasi. Hal ini telah dibuktikan dengan penurunan volume kaki tikus pada kedua perlakuan sama yaitu pada jam ke 4. Namun potensi natrium diklofenak masih lebih baik jika dibandingkan dengan sari buah walaupun belum mampu mengembalikan ke volume kaki normal tikus.

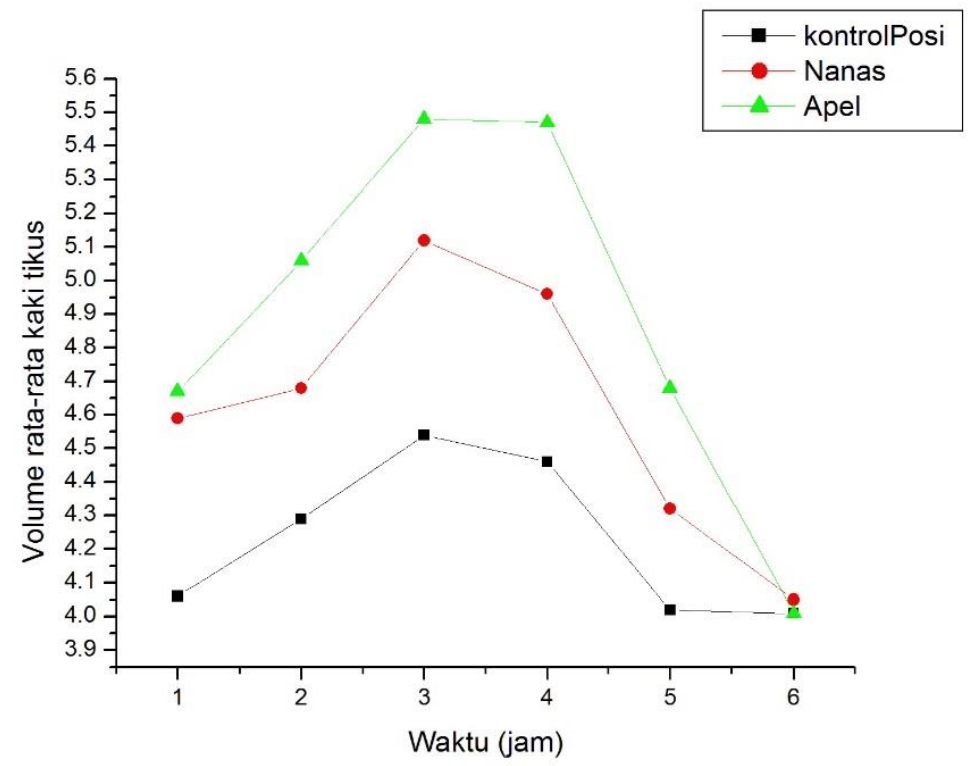

Gambar 2. Grafik perbandingan penurunan volume kaki tikus putih kelompok konsentrasi sari buah nanas $60 \%$ dan apel hijau 56\% dengan kontrol positif

\section{KESIMPULAN}

Sari buah nanas dan apel hijau memiliki aktivitas antiinflamasi pada konsentrasi nanas $60 \%$ dan apel hijau $56 \%$ serta potensinya masih lebih kecil dibandingkan dengan natrium diklofenak $50 \mathrm{mg}$. 


\section{DAFTAR PUSTAKA}

Contreras, A., Paape, M.J., Miller, R.H., Corrales, J.C., Luengo C., and Sánchez, A., 2009. Effect of bromelain on milk yield, milk composition and mammary health in dairy goats. Journal Trop Anim Health Prod, Vol 41.

Hoffmann, D. 2003. Medical Herbalism: The Science and Pratice of Herbal Medicine. Jurnal Pangan dan Agroindustri Vol. 3 No 2.

Katzung, BG. 2006. Basic and Clinical Pharmacology 10th edition. EGC: Jakarta

Morikawa. 2003. Inhibitory effect of quercetin on carrageenan-induced inflammation in rats. Elsevier. Vol 74

Mycek. J.M. 2001. Farmakologi Ulasan Bergambar Edisi Dua. Penerbit Widya Medika: Jakarta

Sudjarwo, Sri Agus. 2005. Anti-inflammatory and analgesic effect of bromelain in mice and rats. Journal Universa Medicina. Vol 24 No 4. 